DOI https://doi.org/10.30525/978-9934-26-184-8-17

\title{
ФОРМУВАННЯ У ФАХІВЦІВ НАВИЧОК ДОСЛІДЖЕННЯ ТА ЗБЕРЕЖЕННЯ МИСЛИВСЬКОЇ ФАУНИ НА ТЕРИТОРІЇ ДП «СОЛОТВИНСЬКЕ ЛІСОВЕ ГОСПОДАРСТВО»
}

\section{Турак О. Ю.}

кандидат сільськогосподарських наук, дочент кафедри лісового і аграрного менеджменту факультету природничих наук ДВНЗ «Прикарпатський наџіональний університет імені Василя Стефаника»

\section{Турак О. Д.}

викладач кафедри лісового і аграрного менеджменту, факультету природничих наук

ДВНЗ «Прикарпатський національний університет імені Василя Стефаника»

\section{Стасинець Ю. В.}

заступник голови громадської ради при Івано-Франківському обласному управлінні лісового та мисливського господарства, магістр групи ЛГ(з) - 1 м м. Івано-Франківськ, Україна

Біорізноманіття України є іiі національним багатством, збереження та невиснажливе використання якого визнано одним 3 пріоритетів державної політики в сфері природокористування, екологічної безпеки та охорони природного довкілля, невід'ємною умовою екологічно збалансованого соціально - економічного розвитку. Займаючи менше $6 \%$ площі Європи, Україна володіє близько $35 \%$ iï біорізноманіття. Сьогодні біорозмаїття України нараховує понад 72 тис. видів флори, мікробіоти і фауни. Фауна налічуе 45 тис. видів, 3 них: комахи -35 тис., членистоногі без комах $-3,4$ тис., черви $-3,2$ тис.; хребетні представлені рибами i 74 
круглоротими (170 видів і підвидів), земноводними (17 видів), плазунами (21 вид), птахами (близько 400 видів), ссавцями (108 видів). За оцінками експертів, ще не описано третини видів, більшості грибів і членистоногих.

У науковій літературі існує декілька визначень поняття «біорізноманіття». Найбільш поширені серед них біорізноманіття - це всі види рослин, тварин та мікроорганізмів,що живуть на Землі, а також екосистем, частиною яких є живі організми, i екологічні процеси, в яких вони беруть участь. Інше визначення, більш складне, подає В.В. Снакин: різноманіття біологічне число різноманітних типів біологічних об'єктів або явищ і частота їх трапляння на фіксованому інтервалі простору і часу, які в самому загальному випадку відтворюють складності живої речовини, здатність до саморегуляції своїх функцій і можливості різностороннього використання [1, с. 280].

Основні загрози біорізноманіттю пов'язані 3 негативною антропогенною діяльністю, що полягає у знищенні природного середовища існування тваринного світу і місць зростання рослин, їх фрагментації і деградації; глобальній зміні клімату; екологічно незбалансованій експлуатації, поширенні чужорідних видів, хвороб і шкідників [2, с. 23].

Природне середовище життя тварин і місця зростання рослин знищуються через високу розораність грунтів, вирубування лісу, осушення або обводнення територій, промислове та дачне будівництво. Спостерігається різке зменшення площі територій водно-болотних угідь, степових екосистем, природних лісових екосистем, які є основою для збереження біорозмаїття. Тому до другого видання Червоної книги України (1994р., 1996 р.) включено утричі більше видів грибів і рослин (541 вид) і 382 види тварин (збільшено в 4,5 рази) порівняно з першим виданням. До третього видання Червоної книги України (2009р.) занесено 542 види тварин:, а до четвертого видання (2021р.) 687 видів тварин. Фрагментація середовищ життя тварин і місць зростання рослин, ландшафтів, екосистем відбувається внаслідок поділу цільних екосистем при будівництві мережі транспортних комунікацій (доріг, автострад), трубопроводів, водосховищ i зв'язаних 3 ними іригаційних споруд (дамб, гребель, насосних 
станцій) і т.д. Забруднення природного середовища призводить до появи в трофічних ланцюгах шкідливих речовин, що породжує хронічну інтоксикацію рослин і тварин. Вміст цинку, марганцю, заліза, нікелю, міді і кобальту у водних об’єктах Полісся, Лісостепу і Степу перевищує нормативні величини у 2-12 разів. Унаслідок Чорнобильської катастрофи забруднено радіонуклідами близько 4 млн. га лісів, з яких 157 тис. га є непридатними для господарського використання, а ще 1,5 млн. га - для використання недеревних харчових і лікарських ресурсів [3, с. 33].

Дослідження та збереження мисливської фауни є важливим у формуванні здобувачів вищої освіти першого (бакалаврського) та другого (магістерського) рівня спеціальності 205 Лісове господарство, практичних навичок для застосування у цій сфері. Студенти вчаться розв'язувати складні задачі і проблеми у сфері лісового господарства при здійсненні професійної діяльності або у процесі навчання, що передбачає проведення досліджень, які характеризуються комплексністю та невизначеністю умов.

Загальна площа держлісфонду ДП «Солотвинське ЛГ» становить 20,8 тис.га. На території держлісфонду переважаючими наступні тварини:

Тритон карпатський (Lissotriton montandoni) вид тритонів роду Lissotriton, ендемік Карпатських гір. Від близьких видів відрізняється відсутністю спинного гребеня. Підвидів не виділяють. Інші назви: Водяна ящірка. Тритон карпатський

- ендемік Карпат. Водиться у гірській та передгірній частинах цього регіону. Поширення пов'язане із широколистяними, ялиново-смерековими лісами, криволіссям, гірськими луками полонинами, хоча часто трапляється і в субальпійському поясі (на полонинах). Вид занесено до Червоної книги України (категорія «вразливі види»), а також до Додатку II «Конвенції з охорони дикої флори і фауни та природного середовища існування в Європі» (категорія «види, що підлягають особливій охороні») та до Червоного списку хребетних Міжнародного союзу охорони природи (МСОП). На території дослідження зустрічається по водоймах Гутянського лісництва, кв. 37, вид. 20, кв. 3, вид. 15, Солотвинського, Росільнянського, кв. 32, вид. 36, 
Богородчанського, Манявського, Яблунського лісництв кв. 9, вид. 2, кв. 45 вид. 3.

Саламандра вогняна, або плямиста (Salamandra salamandra) тварина класу земноводних роду Саламандра (Salamandra). Назва «плямиста саламандра» відноситься також і до іншого виду, Ambystoma maculatum, як і родова назва посилається на велику групу саламандр - хвостатих земноводних із струнким тілом. Надає перевагу біотопам 3 товстим шаром лісової підстилки та моху. На території ДП «Солотвинське ЛГ» вона зустрічається по угіддях Солотвинського, Росільнянського, Богородчанського, Манявського та Гутянського лісництв.

Глушець, або глухар (самиця - готка), готур (Tetrao urogallus) - вид птахів роду тетеруків (Tetrao), один із найбільших птахів Українських Карпат. Глухар - характерний мешканець тайги, поширений в Українських Карпатах, у зоні хвойних лісів до верхньої межі лісу. На досліджуваній території виявлені у Гутянському лісництві, кв.47, вид. 17-20, кв. 48, вид. 1, 2, 9, 26.

Пугач (Bubo bubo), птах з родини Совові (Strigidae). Один з 13-ти видів роду, єдиний вид роду у фауні України. На території ДП «Солотвинське лісове господарство» гніздиться в дуплах старих дерев у Богородчанському лісництві, кв. 23, 31 .

Лелека чорний (Ciconia nigra) - вид птахів з роду Лелека, родини Лелекових. Веде потайний спосіб життя. Один з 5-ти видів роду; один з 2-х видів роду у фауні України. В Україні гніздовий, перелітний птах. Оселяється переважно біля лісових озер чи лісових боліт. На досліджуваній території гніздиться по деревах у розгалуженні головного стовбура, або на великих бічних гілках на висоті 3-20м у Росільнянському лісництві, кв. 1,6,11,12,16,17,21.

Канюк звичайний (Buteo buteo) - вид хижих птахів родини яструбових. В Україні найбільш численний хижий птах; у різних регіонах осілий, кочовий або перелітний. На території ДП «Солотвинське лісове господарство» зустрічається в угіддях всіх лісництв окрім Гутянського лісництва.

Жовна зелена, дятел зелений (Picus viridis) - вид птахів роду Жовна родини Дятлових. Один з двох видів роду у фауні України. В Україні гніздовий, осілий та кочовий вид; представлений номінативним підвидом $P$. v. viridis. На території ДП 
«Солотвинське ЛГ» зустрічається в угіддях всіх лісництв окрім Гутянського.

Тхір лісовий, тхір звичайний або тхір темний (Mustela putorius) - ссавець ряду Хижих, що представляє рід Mustela 3 родини куницевих. Цінний хутровий звір. Тхір чорний - типовий звір широколистяних лісів Полісся і Лісостепу, частий мешканець сільських садиб та курників. 32009 року в Україні під охороною. У Карпатських горах більш ніж на $1000-1200$ м над рівнем моря не піднімається. На території дослідження зустрічається по угіддях Солотвинського лісгоспу.

Видра річкова (європейська, звичайна) (Lutra lutra) - вид видри, широко поширений в Свропі й Азії. В Україні здебільшого водиться в річках Полісся та Лісостепу. Зрідка трапляється і в степовій зоні. Гірськими річками Карпат видра підіймається досить високо в гори. Хутро блискуче, темно-буре. Місця оселення - річки, озера, стариці, ставки. Видра занесена в Червону книгу України. На території ДП «Солотвинське лісове господарство» поширена на території Богородчанського (кв. 24-26), Гутянського (кв.54, 58), Росільнянського (кв. 1, 6,16, 17) лісництв.

Куниця лісова, європейська куниця, або жовтодушка (Martes martes) - хижий ссавець роду Куна (Martes) родини Мустелових (Mustelidae). Розміром більша за свійського кота. На відміну від своєї родички Куни кам'яної (Martes foina), куна лісова уникає людських поселень. Веде переважно деревний спосіб життя. Зустрічається на угіддях всіх лісництв.

Борсук європейський, або лісовий (Meles meles) - вид класу Ссавці (Mammalia) ряду Хижі (Carnivora) родини Куницеві (Mustelidae). Тварини цього виду ведуть наземний спосіб життя, риють підземні сховища - нори - складної будови. Активні переважно в темний час доби. Після набуття Україною незалежності цей вид було включено до другого видання «Червоної книги України» (ЧКУ) (1994).

\section{Література:}

1. Яцик Р.М., Гайда Ю.І. Комплексна оцінка карпатських лісових генетичних резерватів листяних порід. Збереження та 
відтворення біорізноманіття Горган: наук. практ. конф. Надвірна, 2006. С. 280-281.

2. Криволуцкий Д. А. Жизненные формы и биоразнообразие животных. Бюлл. МОИП, 1999. Т. 347. № 5. С. 23-30.

3. Гайда Ю.I., Яцик Р.М., Марчук О.О., Парпан В.I. Основні етапи реалізації процесу збереження та використання лісових генетичних ресурсів в Україні.Науковий вісник НЛТУ України: зб. наук.-техн. праць. Львів: РВВ НЛТУ України. 2008. Вип. 18.10. C. 33-41. 